Inonu University Journal of Art and Design (2021) ISSN: 1309-9876 E-ISSN: 1309-9884

Available online at http://dergipark.gov.tr/iujad Inonu University Journal of Art and Design Faculty Homepage: http://www.inonu.edu.tr/tr/gsf

\title{
Londra İngiliz Kütüphanesi’ndeki Leyla ve Mecnûn Mesnevisi Minyatürlerinde Figürler
}

\section{Figures In Miniatures Of 'Laylā U Majnūn' Manuscript In London British Library Seçil SEVER DEMİRa*}

aDr., İzmir Demokrasi Üniversitesi, Güzel Sanatlar Fakültesi, Fakülte Sekreteri, İzmir/Turkey

Article history: Received 21.10.2021 / Accepted 24.12.2021

\section{ÖZET ABSTRACT}

İran edebiyatının en ünlü mesnevi şairlerinden Nizâmî Gencevi (D.1140-41)'nin günümüze ulaşan en önemli eseri olan "Hamse" Farsça dilinde yazılmış beş adet mesneviden oluşmaktadır. Bu mesneviler: "Mahzen-ül Esrâr", "Hüsrev ve Şirin", "Leyla ve Mecnûn", "Heft Peyker" ve "İskendernâme" başlıklarını taşımaktadır. Hamse, İran başta olmak üzere İslâm dünyasında en çok ilgi gören eserler arasında yer almış Farsça, Arapça, Türkçe gibi pek çok dilde manzum ve minyatürlü nüshaları hazırlanmıştır. Bu çalışmada, 1495/96 yıllarında Sultan Hüseyin Baykara'nın saray kitâbhânesinde üretildiği düşünülen, günümüzde Londra İngiliz Kütüphanesi'nde BL or.6810 envanter numarası ile kayıtlı olarak muhafaza edilen Nizamî'nin Hamse'si ele alınmıştır. Yazmanın içerisindeki "Leyla ve Mecnûn" mesnevisinde yer alan “(106v) Leyla ve Mecnûn Okulda", "(128v) Mecnûn Çölde Salim Tarafından Ziyaret Edildi", "(135v) Leyla Kocası İbn Salim'ın Yasını Tutuyor", (137v) Leyla ve Mecnûn'un Bayılması, "(144v) Leyla'nın Mezarında Mecnûn'un Ölümü" adlı minyatürlerdeki Leyla ve Mecnûn Figürleri analiz edilmiştir. Dönemin baş nakkaşı Bihzâd'a atfedilmiş olan minyatürlerde geleneksel kompozisyon kalıplarının nakkaşa özgü yorumla kullanıldığı, dikey ve yatay eksenlerin dengeli kesişimi ile kompozisyonda birbiriyle orantılı alanlar oluşturulduğu, her minyatürdeki Leyla ve Mecnûn figürünün birbiriyle örtüşerek kronolojik olarak gençlikten yaşlılığa doğru değişim gösterdiği, figürlerin yaşadıkları hüzün ve ısdırabın yüz ifadelerinde net olarak yansıtıldığı; figürlerin yaşadıkları coğrafyanın geleneksel kıyafetleri ve takıları ile resmedildiği sonucuna varılmıştır.

Anahtar Kelimeler: Nizamî Gencevi, Leyla ve Mecnûn, Bihzâd, Minyatür, Londra İngiliz Kütüphanesi BL or.6810
Khamsah the most important work of Niẓāmī Ganjavī (D.1140-41), one of the most famous masnavi poets in Iranian literature, consists of five masnavies written in Persian. These masnavis are titled: 'Makhzan al-asrār', 'Khusraw u Shīrīn', 'Laylā u Majnūn' and 'Haft paykar' and 'Iskandarnāmah'. Since its writing, Khamsah has been among the most popular works in the Islamic world, especially in Iran, and copies of manzum and miniature have been prepared in many languages such as Persian, Arabic and Turkish for the palace and other dignitaries. In this study, Nizāmī's Khamsah, which is thought to have been produced in Sultan Husayn Bāyqarā's palace in $1495 / 96$ and is now stored in the British Library of London with the inventory number BL or.6810. Laylā and Majnūn masnavi which is included in the manuscript Layla and Majnun in miniatures named are "(106v) Laylā and Majnūn at school", "(128v) Majnūn was visited by Salīm in the desert", "(135v) Laylā mourns her husband Ibn Salīm", "(137v) Fainting of Leyla and Mecnûn", “(144v) Majnūn's death in Laylā's tomb" figures of miniatures were analyzed. It has been revealed that the traditional composition patterns specific to the muralist are used in the designs, and proportional areas are created in the composition with the balanced intersection of the vertical and horizontal axes and the figure of Leyla and Majnun in each miniature. Chronologically, the transition from youth to old age was considered, the sadness and suffering of the figures were clearly reflected in their facial expressions, and these figures were depicted with the traditional clothes and jewelry of the geography they lived in.

Keywords: Nizāāī Ganjavī, Khamsah, Laylā u Majnūn, Bihzâd, Miniature, British Library in London BL or.6810

\section{Giriş}

İran edebiyatının en ünlü mesnevi şairlerinden biri olan Nizamî Gencevi'nin (D.1140-41) günümüze ulaşan en önemli eseri Farsça dilinde yazılmış beş adet mesneviden oluşan "Hamse"dir. Bu mesneviler: "Mahzen-ül Esrâr", "Hüsrev ve Şirin", "Leyla ve Mecnûn”, "Heft Peyker" ve "İskendernâme" olarak adlandırılmıştır. Hamse, 12. yüzyıldan itibaren, İran başta olmak üzere İslâm dünyasında en çok ilgi gören eserler arasında yer almış gerek saray gerekse diğer ileri gelenler için çok sayıda Farsça, Arapça, Türkçe, Urduca (Durmuş, 2003: 159) ve diğer bazı dillerde manzum ve minyatürlü nüshaları hazırlanmıştır. Nüshalar günümüzde başta İran olmak üzere ülkemizde, Orta Doğu, Avrupa ve diğer çeşitli yazma eser koleksiyonlarında yer almaktadır. Bu çalışmanın evrenini Hamse'nin 1495/96 tarihli, Sultan Hüseyin Baykara'nın 
saray kitâbhânesinde üretildiği düşünülen, günümüzde Londra İngiliz Kütüphanesi BL or.6810 envanter numarasıyla kayıtlı minyatürlü el yazma nüshası; örneklemini ise yazma eserin içinde bir bölüm olan "Leyla ve Mecnûn" mesnevisinde yer alan ve aynı zamanda dönemin Başnakkaşı Kemaleddin Bihzâd'a (ö. 1535-36) (Çağman, 1992:147) atfedilen beş adet minyatür oluşturmaktadır. Bu kapsamda öncelikle Mesnevi'nin konusu anlatılmış daha sonra yazmanın $106 \mathrm{v}, 128 \mathrm{v}, 135 \mathrm{v}, 137 \mathrm{v}$ ve $144 \mathrm{v}$ varaklarında bulunan minyatürlerdeki Leyla ve Mecnûn figürleri analiz edilmiştir.

\section{Materyal ve Yöntem}

Bu makalede, Nizâmi-yî Gencevi'nin Hamse adlı eserinin 1495/96 tarihinde istinsah edilmiş, günümüzde Londra İngiliz Kütüphanesi'nde BL or.6810 envanter numarasıyla kayıtlı olan minyatürlü nüshası ele alınmıştır. Esere müzenin açık erişim (http://www.bl.uk/manuscripts/Viewer.aspx?ref=or_6810_f106v) sayfasından ulaşılmıştır. Çalışmanın materyali yazmanın içinde yer alan "Leyla ve Mecnûn" mesnevisi metnini açıklamaya yönelik olarak yapılmış beş minyatür sahnesidir. Dönemin Başnakkaşı Kemaleddin Bihzâd'a atfedilen bu minyatürler "(106v) Leyla ve Mecnûn Okulda”, “(128v) Mecnûn Çölde Salim Tarafından Ziyaret Edildi", "(135v) Leyla Kocası İbn Salim'in Yasını Tutuyor", “(137v) Leyla ve Mecnûn'un Bayılması" ve "(144v) Leyla'nın Mezarında Mecnûn'un Ölümü" konularını anlatmaktadır.

Çalışmada, nitel araştırma yöntemlerinden literatür tarama tekniği kullanılmıştır. Konuyla ilgili geniş bir literatür taraması yapılarak derlenen bilgiler ışığında, orijinal yazmadaki minyatürler metin minyatür ilişkisi bağlamında analiz edilmiş, kompozisyonların zaman, mekân ve kurgu açısından tutarlı olup olmadığı ele alınmıştır. Metnin kronolojisi ile tasvirlerin kronolojisi arasında paralellik olup olmadığı üzerinde durularak minyatür tasarım tekniği ve üslubu özelinde kompozisyonlardaki Leyla ve Mecnûn figürleri sentezlenmiştir.

\section{Bulgular}

\subsection{Nizâmi-yi Gencevî ve Hamse}

Farklı kaynaklarda doğum ve ölüm tarihi hakkında kesin tarih verilmeyen ancak Britannica Ansiklopedisinde kesin tarih belirtilmiş olan tam adı "İlyas Yusuf Nizamî Gencevî" olan "Nizamî" Selçuklu imparatorluğu zamanında, günümüzde Azerbaycan hakimiyetinde olan Gence şehrinde 1141 yılında doğmuş, 1209 yılında ise yine aynı şehirde ölmüştür. Şair Fars edebiyatının en büyük romantik epik şairi olarak kabul edilir (Britannica, The Editors of Encyclopaedia, 2021). Nizâmi-yi Gencevî iyi bir tahsil görmüş, saraydan uzak yaşamış, eserlerini saltanat sahiplerinin talepleri üzerine kaleme almış, milliyet bakımından Türk, sunnî mezhebine mensup, mutasavvuf ve şairdir (Kaska, 2020: 877 ve Akalın,1998:79). Nizâmi'nin (Görsel 1) dil ve edebiyat yanında astronomi, felsefe, coğrafya, tıp ve matematik okuduğu, mûsikiye ilgi duyduğu, Farsça ve Arapça'dan başka Pehlevîce, Süryânîce, İbrânîce, Ermenice ve Gürcüce gibi dilleri de öğrendiği anlaşılmaktadır (Kanar, 2007: 183).

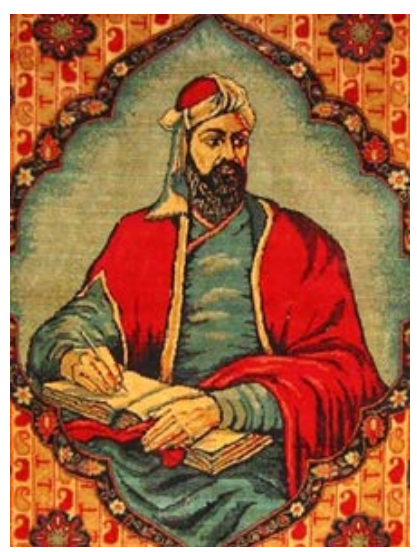

Görsel 1: Nizâmi-yi Gencevî (URL-1, 2021)

Nizâmi yaşadığı dönemin devlet adamları için şiirler yazmış olsa da bir saray şairi değildir ve emirlerle hükümdarların etrafında bulunmak yerine alçak gönüllü bir yaşamı seçmiş, bu nedenle de hem halk hem de yöneticiler tarafından saygı görmüştür. "Hamse", İran ve Türk 
edebiyatlarında aynı şaire ait beş mesnevîden oluşan külliyatların genel adıdır. Hamse yazan şairlere "hamse şairi" veya "hamsenüvis" adı verilmiştir (Arslan, 2007: 306).

Arapça hams (beş) kelimesinin müennesi olan hamse, beş mesneviden oluşan külliyat anlamında ilk defa Nizâmî-i Gencevî'nin Mahzenü'l-esrâr (Gizemlerin Hazinesi), Hüsrev ü Şîrîn, Leylâ vü Mecnûn, Heft Peyker (Yedi Güzeller), İskendername (Büyük İskender Kitabı) adlı Farsça eserleri hakkında kullanılmıştır. Farklı nüshalarında beyit sayısı değişmekle beraber Hamse, yaklaşık 35.000 beyitlik didaktik şiirleri içerir; bunlar yaklaşık 2400 beyitlik tasavvuf konulu bir mesnevi olan "Mahzzenü'l-esrâr"; destansı romantik mesnevilerden oluşan 6.500 beyitlik "Hüsrev ve Şîrin", 4.600 beyitlik "Leyla ve Mecnûn" ve yaklaşık 5.130 beyitlik "Heft Peyker"dir. Diğer mesnevi ise didaktik bir destan olan, yaklaşık 10.500 beyitlik “İskendername”dir (Kanar, 2007:184). Eserin 1175-76 yıllarından başlayarak otuz beş veya kırk yıl gibi bir süre zarfında tamamlandığı düşünülmektedir (Kanar, 2007:184). Selçuklular döneminde ortaya çıkan hamse İran'da en çok Safevîler döneminde revaç kazanmıştır (Kaska, 2020: 877). Hamse ismi ilk kez Nizâmi'nin eseri hakkında kullanılmıştır. Penc Genc (Beş Hazine) adıyla da anılan bu mesnevîlerin taklit edilmesiyle sayıları artmış ve bu eserlere hamse adı verilmiştir (Yazıcı ve Kurnaz, 1997: 499). Farsça edebi türlerin en güzel örneklerinden olan Hamse, bu alanda eser veren şairlere örnek teşkil etmiş; Emîr Hüsrev-i Dihlevî, Şemseddin Kâtibî-i Nîşâbûrî, Molla Abdurrahman-ı Câmî, Feyzî-i Hindî ve Hâcû-yi Kirmânî gibi şairler Hamse'ye nazîre yazmıştır. Hamse'nin nüshaları arasında günümüze ulaşan en eski tarihli yazma 1362 tarihli Paris'te bulunan Fransa Ulusal Kütüphanesi'nde (Supplément persan 1817) bulunan nüshadır (Parrello: 2010; Blochet, 1928: 52). Nizâmi'nin Hamse'si her dönem beğenilen bir eser olduğu için sadece şairleri etkilemekle kalmamış, birçok kez yazılmış ve pek çoğu da minyatürler ile görsel hale getirilmiştir. Özellikle Firdevsi'nin Şehnamesi'yle birlikte Hamse en fazla minyatürü yapılan edebi eserler arasına girmiştir (And, 2002: 273).

\subsection{Leyla ve Mecnûn Mesnevisi}

Leyla ve Mecnûn Mesnevisi Arap, Türk, Fars ve Urdu edebiyatlarında çok popüler olarak ele alınmış olan hüzünlü gerçek bir aşk hikâyesini anlatmaktadır. Mesnevinin ana kahramanlarından birisi olan Mecnûn'un Arabistan yarım adasının ortasında bulunan Necid'de (Görsel 2) yaşayan bir Arap kabilesine mensup Kays b. Mülevvah el-Âmirî adında bir genç olduğu ve 689 yılı civarında öldüğü kabul edilmektedir.

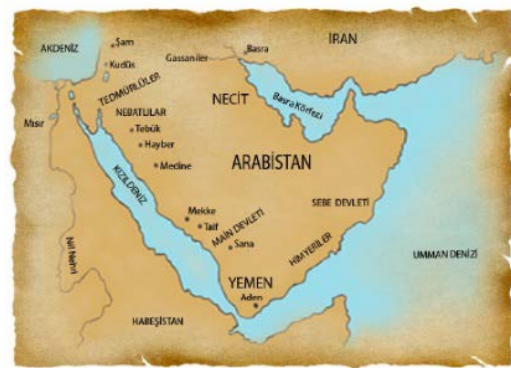

Görsel 2: Leyla ve Mecnun un yaşadığı Necid Bölgesi (URL-2, 2015)

Emevi ailesine mensup bir bedevi ve aynı zamanda şair olan Kays'ın Leylâ'ya duyduğu aşk yüzünden aklını kaybetmesi sebebiyle kendisine takılan Mecnûn lakabı daha sonraları asıl adının yerini almıştır (Durmuş 2003:159) Mesnevinin diğer kahramanı olan Leyla'nın ise Mecnûn'un amcasının kızı olan Leyla bint Mehdi ei-Amiriyye olduğu bilinmektedir. Arabistan yarımadasının ortasındaki çöllerde ortaya çıkan hikâye eş zamanlı olarak İran'da da yankı bulmuş, ilk defa aslen Emevi soyundan gelen Bağdat'lı alim Ebü'l-Ferec ei-İsfahani (Ö. 967) (Kılıç,1994:316) konuyla ilgili olarak kendi zamanına kadar gelen rivayetleri kronoloji kaygısı taşımadan sıralayarak yazmıştır. Bu divana şiirlerin arasına küçük mensur parçalar eklenerek bir hikâye şekli verilmiştir. Leyla ve Mecnûn hikayesi, 10. yüzyılda Arap dili ve edebiyatı alimlerinin türlü şekilleriyle naklettikleri bir halk hikayesi haline dönüşmüştür (Durmuş, 2003: 159).

İran'da 1188 yılında Nizâmî Gencevî tarafından yazılmış olan Leylâ ve Mecnûn mesnevisi ise şairin Hamse adlı esrinin içinde yer almıştır. Mesnevi Şirvânşah Ebu'l-muzaffer Ahsitan bin Minûçihr için yazılmıştır. Oldukça beğenilen eser, daha sonra Arap, Fars, Türk ve Urdu edebiyatında çok sayıda şair tarafından te'lîf edilmiştir. Mesnevinin ilk kaynağını Ebu'l-Ferec 
İsfahânî'nin 10. yüzyıl sonlarında yazdığı Kitâbu'l-Egânî adlı kitapta yer alan Leylâ ile Mecnûn hikâyesi oluşturmaktadır. Nizâmî, Leylâ ile Mecnûn eserini kaleme almadan önce Kitâbu'lEgânî'yi incelemiş ve metinden yararlanmıştır (Yavuz, 2018:706). "Mefûlü mefâilün feûlün" vezniyle yazılmış olan eser yaklaşık 5000 beyitten oluşmaktadır. Konusunu Arap kültüründen almakla birlikte kahramanları İranlı kimliğine büründüren Nizâmî üslûbu, kurgulaması ve ifadesiyle en başarılı eserini ortaya koymuş, birçok nazire arasında Klasik Türk edebiyatının en büyük şairlerinden Fuzûlî (Ö.1556)'nin 1536 yılında aynı adla yazdığı eseri ona yaklaşabilmiştir (Kanar, 2007: 184).

Arap edebiyatındaki Leyla ve Mecnün hikayesi ile Fars edebiyatındaki birbirine oldukça benzemekte yalnızca hikâyenin baş kısmında tanışmalarının okulda değil; kabilelerinin hayvanlarını otlatırken gerçekleştiği şeklindendir. Hikâyeye göre kahramanların aşklarının ortaya çıkması üzerine Leyla çadırda alıkonur ve Kays'a gösterilmez. Bunun üzerine Kays'ta aşkın ilk ıstırabı başlar; babasına Leyla'yı istemesini söyler. Ancak aşkları sebebiyle kızın adı dillere düşüp namusu lekelendiği için bu teklif reddedilir ve Leyla bir başkasıyla evlendirilir. Kays ıstırabın tesiriyle aklını büsbütün kaybeder. Dönemin ileri gelenleri aralarını bulak için girişimde bulunurlar ancak bu girişimleri sonuçsuz kalır. Babası şifa ümidiyle Mecnûn'u Mekke ve Medine'ye götürürse de Mecnûn Allah'a aşkını arttırması için dua eder ve çöllere kaçarak vahşi hayvanlarla birlikte yaşamaya başlar. Öte yandan Leyla Mecnûn'un aşkıyla ıstırap içinde ölür. Mecnûn da onun için ağıtlar söyleyip aşkının acılarını terennüm ederek çöllerde dolaşmaya devam eder. Nihayet bir gün ölüsü bulunur (Durmuş, 2003: 159).

Nizâmi'nin yazdığı versiyonla oluşan Fars Edebiyatındaki Leyla ve Mecnûn hikayesi: İran şairlerinin eserlerinde çeşitli vesilelerle Leylâ ve Mecnûn adları zikredilmiş ve şiirlere konu olmuştur. Bu isimlere ilk defa Menûçihrî (ö. 432/1041) ve Baba Kûhî-i Şîrâzî́nin (ö. 442/1050) divanlarında rastlanmaktadır. Bu şairler muhtemelen, Leylâ ve Mecnûn adlarını halk arasındaki sözlü rivayetlerden veya anonim bir Leylâ ve Mecnûn hikâyesinden almışlardır. Leylâ ve Mecnûn adlarına Enverî ve Hâkānî-yi Şirvânî'nin divanlarında da rastlanır. Halk arasında yaygın olmasına rağmen konu Nizâmî-i Gencevî̀ye kadar (ö. 608/1211-12) şairler tarafından müstakil olarak ele alınmamıştır. Şirvanşahlar'dan Ahsitân b. Menûçihr, Nizâmî'den konuyu manzum olarak kaleme almasını isteyince Nizâmî, dört aydan az bir süre içinde yaklaşık beş bin beyitlik bir mesnevi yazmış, Arap kökenli olan hikâyeye hükümdarın hoşuna gitmesi için bir İranlı havası vermeye çalışmıştır. Nizâmî, Arap kaynaklarındaki malzemeyi kullanmakla beraber çöl ve bedevî hayatıyla ilgili olayların çoğunu şehirlerde geçmiş gibi göstermiştir.

“Nitekim eser, Leylâ ve Mecnûn çölde hayvan otlatırken değil okulda okudukları sırada başlar. Mecnûn'u savunan Nevfel bir Arap emîri olmayıp bir İran prensidir. Ayrıca Nizâmî eserine Zeyn ve Zeynel adında iki şahıs eklemiştir. Zeyn rüyasında Leylâ ve Mecnûn'un ancak âhirette birleşebileceklerini görür. Konuda en önemli değişiklik ise hikâyenin sonuyla ilgili bölümlerde yapılmıştır. Leylâ istemediği halde İbn Selâm adlı bir kişiyle evlendirilir, ancak kendisine dokunmasına izin vermez. İbn Selâm da ona olan aşkından dolayı ölür. Leylâ Mecnûn'u arayıp bulur. Fakat Mecnûn'un aşkı ilâhî aşka dönüştüğü için Leylâ'ya gereken ilgiyi göstermez, bu sebeple Leylâ üzüntüsünden ölür. Ardından Mecnûn da onun mezarı üzerinde ölür ve onun yanına gömülür. Aşklarının ilâhî aşka dönüşü, dünyanın fâniliği ve ölüm gibi konular esere tasavvufí bir nitelik kazandırmış, yer yer zikredilen gazeller de eserin etkinliğini arttırmıştır" (Yazıcı, 2003:160).

Nizâmî'den itibaren büyük ilgi gören Leylâ ve Mecnûn mesnevisi birçok şair tarafından ele alınmışsa da hiçbiri onun seviyesine ulaşamamıştır. Nizâmî'den sonra bu alanda yazılan en başarılı eser, Emîr Hüsrev-i Dihlevî'nin 1299 yılında kaleme aldığı hamsesi içindeki Mecnûn u Leylî'sidir. Şeyh Nizâmeddin Evliyâ ile Delhi sultanına ithaf edilen mesnevi Nizâmî'nin eserinden daha kısadır (2660 beyit) ve genellikle bir Hint şehzadesinin macerası niteliğini taşımaktadır. Eserde tasavvufî konulara hiç yer verilmemiştir (Yazıcı 2003:160). 
Leylâ ve Mecnûn mesnevisi aynı zamanda Avrupa edebiyatlarındaki Romeo and J uliet, Tristan et Yseult gibi aşk klasikleri arasında da yerini almıştır. Leyla ve Mecnûn mesnevileri üzerine pek çok tez ve bilimsel çalışma yapılmış, çok sayıda müstakil eserler yayımlanmıştır (Pala, 2003: 161). Türk edebiyatında çok ilgi gören, aşkın ve âşıklığın sembolü olarak gösterilen Leyla ve Mecnûn mesnevisinin (Çavuşoğlu, 2013:647) edebiyatımızdaki tesiri çok yüksek olmakla birlikte yazılmış olan Leylâ ve Mecnûn sayısı otuzu bulmaktadır. Ancak eserin günümüze ulaşan nüshaları kütüphanelerde ve özel koleksiyonlarda yirmi civarındadır. Eserin Millî Eğitim Bakanlığı tarafından basılan çevirisi Ali Nihat Tarlan tarafından 1990 yılında yapılmıştır. Prof. Dr. A. Naci Tokmak da Nizâmi'nin Leyla ile Mecnûn Mesnevisini Farsça aslından Türkçeye tercüme etmiş, eserin Farsça aslından çevriyazısı ile neşrini manzum olarak 2013 yılında yayımlamıştır.

\section{4. İngiliz Kütüphanesi Oryantal El yazmaları Koleksiyonu 6810, Nizâmi’nin Hamse'si}

Nizâmi-yî Gencevî'nin 1140 veya 41 tarihli Hamse adlı eserinin 1495/96 yılında Herat'ta telif edilmiş olan minyatürlü nüshası Herat ve Timurid tarzında 1 çift ve 20 tek sayfa minyatür içermektedir. Minyatürlerin alt kenarlarına sanatçılarının kim olduğuna dair daha sonra eklenmiş olan çeşitli atıflar bulunmaktadır. Varak 284r'de bulunan minyatürde eserin aynı zamanda hazırlanış tarihi olan $900 \mathrm{AH}$ (1494/95) belirtilmektedir. Yazma 17 x 24,5 cm ebadında 303 varaktan oluşmaktadır. Eserin dili Farsçadır. Nestalik hatla bir sayfada 4 sütuna 25 satır halinde metin yazılmıştır. Yazmanın varak $3 r$ ve varak $6 r$ 'deki serlevha sayfası tezhiplidir. Eserin Nakkaşları ise Bihzâd, Mîrak, Abdül-el Rezzak ve Kâsım Ali olarak belirtilmiştir. Eserin hamisi olarak Hüseyin Baykara'nın adı geçmemekle birlikte varak 62b'deki minyatürde bu yazmanın Hüseyin Baykara'nın emirlerinden Emir Ali Farsî Bârlas için hazırlandığı yazılıdır. Çok sayıda el değiştiren eser 27 Şubat 1908'de British Museum mülkiyetine geçmiştir. Eserde 1564/65'ten 1782'ye kadar uzanan yetmişten fazla yazı ve mühür bulunmaktadır (Görsel 3).
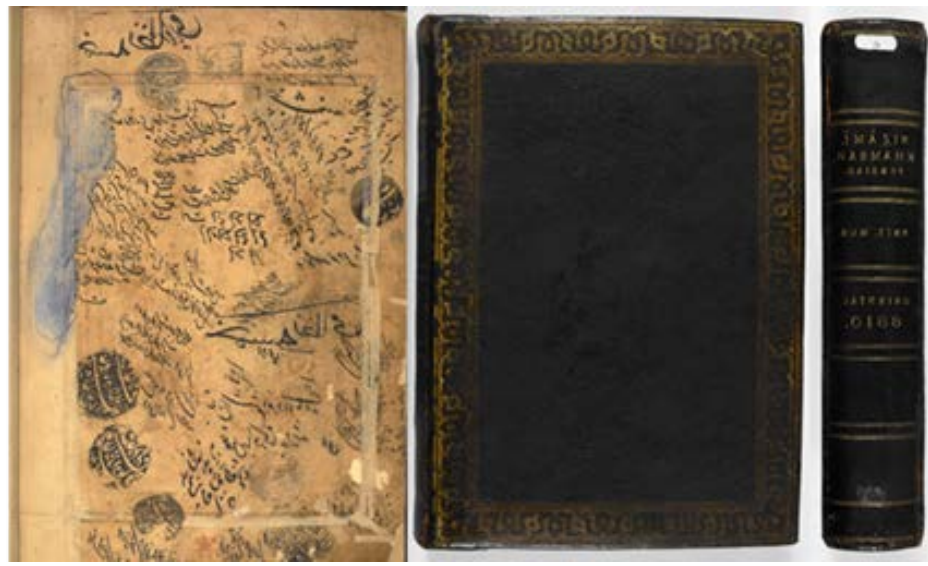

Görsel 3: Or. 6810, Nizamî'nin Hamse'si (URL-3, 1490-1499)

Eser hakkında çok sayıda yayın yapılmış olup bu yayınlar arasında ilk ve en kapsamlıları: Norah M. Titley, Miniatures from Persian Manuscripts: a Catalogue and Subject Index of Paintings from Persia, India and Turkey in the British Library and the British Museum (London, 1977), p. 141 .

F. R. Martin, T. W. Arnold, The Nizâmî Ms., Illuminated by Bihzâd, Mirak and Qasim Ali, Written 1495 for Sultan Ali Mirza Barlās, Ruler of Samarquand, in the British Museum (Or. 6810) (Vienna, 1926).

John Seyller, "The Inspection and Valuation of Manuscripts in the Imperial Mughal library", Artibus Asiae 57 no 3/4 (1997), pp. 243-349, şeklinde sıralanabilir.

Eserde yer alan mesneviler; Makhzan el-asrār (3v-29r), Hüsrev ve Şirin (30v-97v), Haft Peyker (147v-198v), Leyla ve Mecnûn (98v-146v), İskendername (199v-303r) yer almaktadır. (Eserin açık erişim sayfası: http://www.bl.uk/manuscripts/FullDisplay.aspx?ref=Or_6810) şeklindedir. 


\subsubsection{Leyla ve Mecnûn (98v-146v)}

Bu çalışma kapsamında, 48 varaktan oluşan Leyla ve Mecnûn mesnevisi metnini açıklamaya yönelik olarak beş adet minyatür yapıldığı tespit edilmiştir. Bu minyatürler hikâyenin ilerleyişine göre metin ile paralellik göstererek yerleştirilmiş tasvirlerdir. Her minyatür varağı dıştan dışa 17 × 24,5 cm ebadındadır. Beş adet minyatür, eserin açık erişim sayfasında isimlendirildiği şekilde ayrı ayrı başılılar halinde analiz edilmiştir. Bu minyatürler dönemin baş nakkaşı Kemaleddin Bihzâd'a atfedilmiştir.

\subsubsection{1. (106v) Leyla ve Mecnûn Okulda}

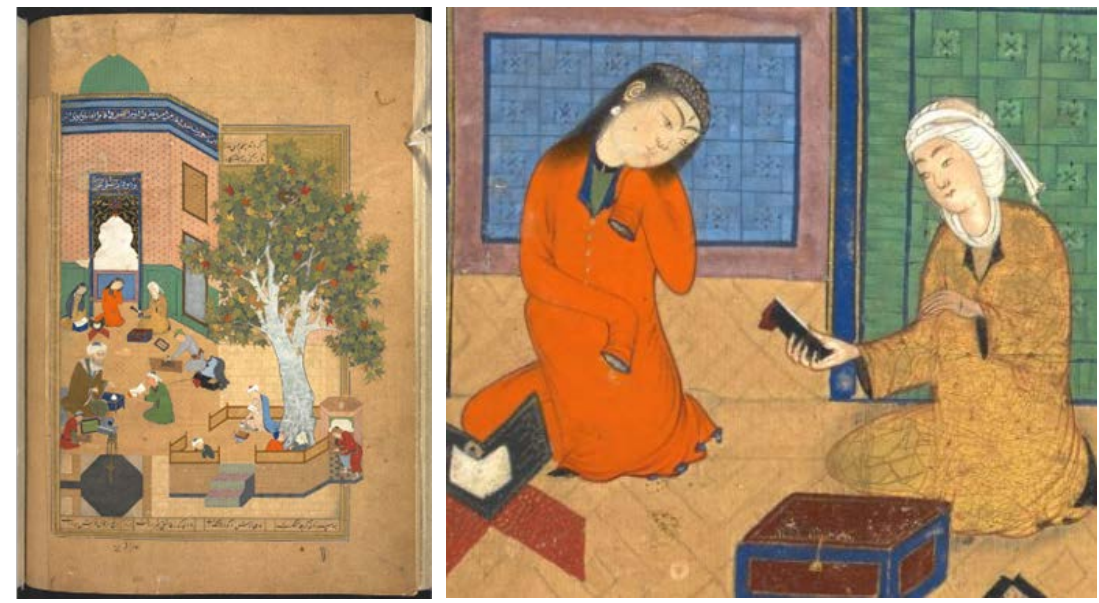

Görsel 4: Leyla ve Mecnûn Okulda (URL-4, 1490-1499)

Yazmanın 106v varağında bulunan minyatür, dikdörtgen formda yatay eksende iki kısımdan oluşan bir kompozisyona sahiptir. Minyatür sahnesi muhteşem güzellikte işlenmiş çınar ağacı yaprakları ve okul binası kubbesi ile kesintiye uğrayan altın cetvellerle çevrilidir. Renkli yapraklı çınar ağacı adeta nakkaş Bihzâd'ın imzası gibidir. Bir okul bahçesinde geçen konuda, üç gurup halinde bahçeye dağılmış şekilde yerleştirilmiş on üç figür görülmektedir. Sahnede en alttaki figür gurubunda en sağda okulun dışındaki bir çeşmeden su alan yaşlı bir kadın vardır. Okulun bahçesindeki çınar ağacının altındaki kare planlı oturma alanında iki çocuk karşılıklı tartışarak konuşmakta, arkalarındaki tek çocuk derste de olsa uyuklamakta, ağacın gövdesinin altında yerde diz çökmüş olan diğer erkek çocuk figürü ise elindeki kamış kalemi mürekkep hokkasına batırmış yazı yazmaya hazırlanmaktadır. Sahnenin sol kenarında ortada yerde diz çökmüş şekilde oturan öğretmen figürü ve etrafında kendisine soru sormakta olan üç erkek çocuk figürü daha yer almaktadır. Sahnenin üst eksenindeki son figür gurubunda ise olayın baş kahramanları Leyla ve Mecnûn yerde diz çökerek karşılıklı oturmuşlar, Mecnûn elindeki kalemlik tarzı bir malzemeyi Leyla'ya uzatır şekilde görülmektedir. Leyla'nın arkasında ise sahnedeki diğer kadın figürü olan öğrenci kitap okurken resmedilmiştir. Sahnedeki başrol oyuncularından biri olan Mecnûn hardal sarısı renge yakın bir sarı renkte uzun kollu ve uzun boyda bir cüppe giymiş, başına boynunun altından dolanarak başının üstüne uzanan uç kısmı görülen beyaz bir bedevi başlığı takmış, beyaz tenli, çekik gözlü, kiraz dudaklı yakışıklı bir genci temsil etmektedir. Leyla ise sahnede okulun kapısının ve beyaz arka planın tam önüne yerleştirilerek baş kahraman olduğu direkt olarak fark edilmektedir. Leyla çekik birleşik kaşı, siyah saçlı beyaz yuvarlak yüzlü olarak resmedilmiştir. Leyla'nın giydiği uzun boyda ve uzun kollu turuncu renkteki cüppenin kolları içerisinde elleri saklanmıştır. Ellerin elbisenin içerisine saklanması kutsal kişilere atfedilen bir tasarım simgesi olması nedeniyle dikkat çekicidir. Özellikle Leyla figürü sahnenin en üst figür gurubunun merkezine yerleştirilmiş, perspektif göz ardı edilerek diğer tüm figürlerden daha irice çizilmiştir. Bu durum onun sahnenin baş kahramanı olarak dikkat çekmesini sağlamaktadır. Her iki figür de genç sağlıklı ve mutlu iki okul arkadaşını veya iki sevgiliyi yansıtmaktadır. 


\subsection{2. (128v) Mecnûn Çölde Salim Tarafından Ziyaret Edildi}
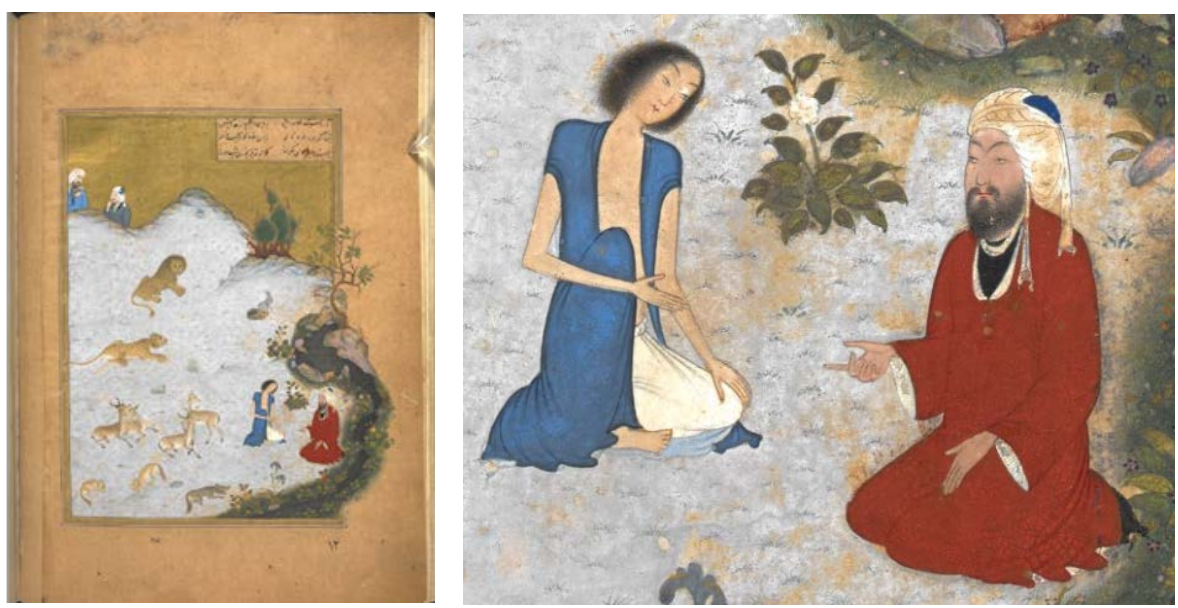

Görsel 5: (128v) Mecnûn Çölde Salim Tarafından Ziyaret Edildi (URL-5, 1490-1499)

Kütüphanenin açık erişim sayfasında "Salim'in çölde Mecnûn'u ziyareti" olarak adlandırılmış sahnede belki de Salim, Mecnûn'a Leyla'dan vazgeçmesini söylemektedir. Hikâyeye göre Leyla Salim'i kendisine yaklaştırmamakta, Salim ise Leyla'nın aşkından hasta düşmektedir. Yazmanın 128 v varağında yer alan minyatür dikdörtgen formda olup sahnenin sağ kenarı yukarıdaki ağacın altından başlayan nehir ile cetvelin dışına doğru kavis yapmıştır. Kompozisyon yatay eksende zemin ve gökyüzü olarak iki kısıma ayrılmıştır. Oldukça geniş açık mavi renkteki zeminde serbest halde yatan ve/veya dolaşan on hayvan figürü yer almaktadır. Hikâyenin aslına göre Necef çölünü temsil eden alanda çölde hayvanlarla iletişim kuran kimi zaman onların sütüyle beslenirken kimi zaman da onları yöneten bu nedenle de kutsallık atfedilmiş olan Mecnûn yerde diz çökerek oturmuştur. Mecnûn, etrafında toplanan vahşi hayvanlardan çeşitli bakımlardan faydalanmakta, ceylanlar tarafından süt ile beslenmekte ve onlarla oynamaktadır. Hayvanlara hükmeden kutsal kişi figürünün kökeni, Yunus Peygamber'e kadar uzanmaktadır. Yunus Peygamber balığın karnından çıktığında dişi bir ceylan tarafından kırk gün boyunca emzirilmiştir. Söz konusu motifin zaman içerisinde sözlü ve yazılı edebiyata işlediği görülmektedir (Sağlam, 2021:1425) öte yandan Hz. Süleyman`ın tüm hayvanlara hükmetmesi, onlarla konuşması, emrinde çalıştırması da buna bir örnek olarak gösterilebilir (Sever, 2020). Kutsal kişilerin hayvanları yönetmesi, hayvanlarla iletişim kurması motifinin Mecnûn için de kullanılması ona ilahi bir kişilik kazandırma sembolü örnek olarak gösterilebilir. Bu sahnede de ceylanlar, pars, kurt ve tavşan gibi hayvan figürleri yer almaktadır. Mecnûn'un karşısında bedevi geleneklerine uygun tasarımda sarığı ve uzun cübbesi ile diz çökerek oturmakta olan sakallı erkek figürü Leyla'nın kocası Salim'dir. Mecnûn aradan geçen yılların verdiği acı ve ıstırap ile çölde yaşadığı belli olacak şekilde zayıflamış, saçı dağılmış, üzerinde sadece şalvarı ve uzun mavi cüppesi ile yakası açık, göğsünden beline kadar çıplak ve diğer figüre göre oldukça perişan görünmektedir. Bu tasvir ile Nakkaş Bihzād Mecnûn'un çölde geçirdiği uzun zamanı ve ilahi aşkı arama çabasını izleyiciye yansıtmıştır. Leyla ve Mecnûn'un şehirden çok uzakta oldukları ufuk çizgisinin üzerine yerleştirilmiş iki erkek figürü ile vurgulanmıştır. 


\subsection{3. (135v) Leyla'nın Kocası İbn Salim'in Yasını Tutuyor}

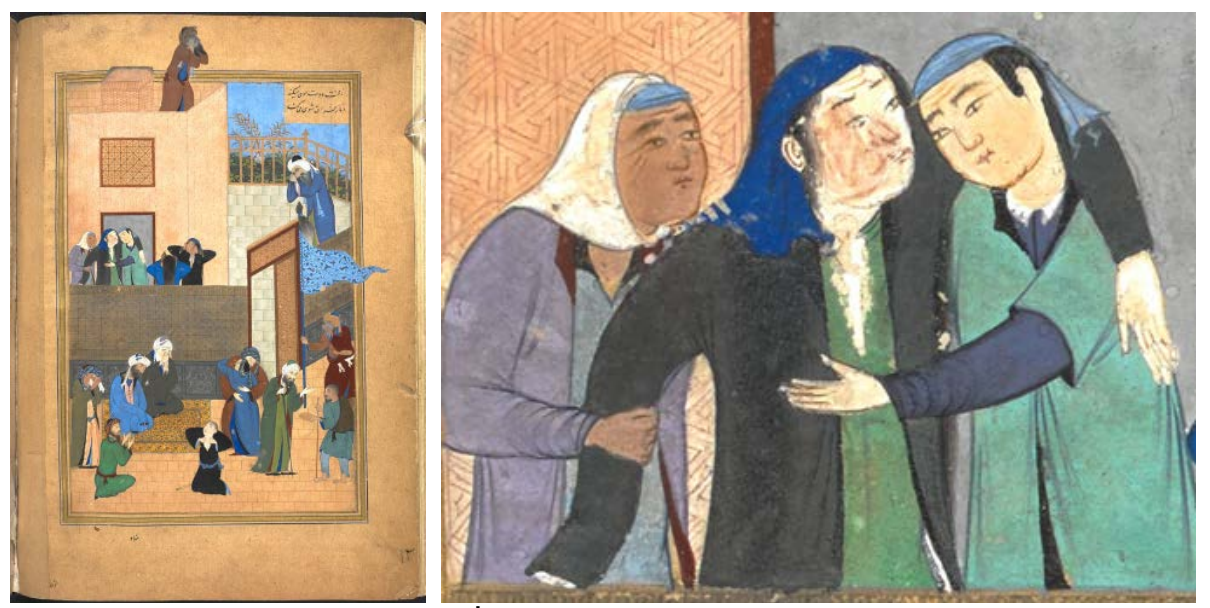

Görsel 6: (135v) Leyla, Kocası İbn Salim'in Yasını Tutuyor (URL-6, 1490-1499)

Mesnevinin 135v varağında yer alan "Leyla, Kocası İbn Salim'in Yasını Tutuyor" konulu minyatür sahnesi yatay eksende üç kısımdan oluşmaktadır. Kompozisyonda en alt eksende sokakta yas tutan insanlar, ikinci eksende evin avlusunda içerisine Leyla'nın da bulunduğu ağlayan insan gurubu; üçüncü ve son eksende ise evin çatısında iki ellerini kulaklarına doğru götürmüş sela okuyan bir erkek figürü görülmektedir. Dikdörtgen planda oluşturulan minyatür kompozisyonu altın cetveller ile çevrelenmiştir. Kompozisyondaki mimari elamanların yüzeyleri ince işçilikle işlenmiş geometrik desenlerle süslenmiştir. Sahnede on yedi insan figürü bulunmaktadır. Hikâyenin ana kahramanlarından olan Leyla sahnede ikinci eksenin ortasında başında mavi örtü ve üzerinde siyah cüppe ile her iki yanında kendisine yürümesine yardım eden koluna girmiş kadınlar ile üzüntü içinde resmedilerek yas tuttuğu açıkça gösterilmiştir. Leyla figürü mesnevideki ilk minyatürde genç kız olarak resmedilmiş iken bu sahnede o günden bu yana uzun yıllar geçtiği açıkça görülmekte orta yaşlı bir kadını temsil etmektedir. Leyla ilk minyatüründeki tipine sadık kalınarak beyaz yuvarlak yüzlü, çekik gözlü, orta boylu olarak tasvir edilmiştir. Kompozisyonda Leyla'nın yer aldığı kısımda seyirciye arkası dönük olan kadın figürü ölüm karşısında duyduğu üzüntü ile saçlarını yolarken resmedilmiştir. Bu figürün karşısındaki diğer kadın figürü ise ellerini yanaklarına dayamış, başını iki yana yaslayarak hareket edecek gibi görünmekte, bu pozisyonu ile acıdan duyduğu üzüntü kolaylıkla anlaşılmaktadır. Minyatür açıkladığı metindeki zaman ve mekân kurgusuna uygun tasarlanmıştır. Mesnevi metninde Salim'in, Mecnûn'a duyduğu aşk nedeniyle Salim'i kendisine yaklaştırmayan Leyla'nın aşkından öldüğü belirtilmiştir. Cenaze töreninde, Leyla'nın kocasının ölümünü bahane ederek Mecnûn'a duyduğu aşkın acısı için ağlayıp yas tuttuğu anlatılmaktadır. Buradaki tasvirde Leyla figürünün mesnevinin metninde anlatılan duygu durumuna paralel jest ve mimikle resmedildiği söylenebilir. Leyla figürü dışındaki diğer figürler daha derin üzüntü ifadesi göstererek ağlayıp saçını yolmakta, elinde mendille burnunu silmekte, birbirlerine sarılarak acılarını paylaşarak ağlamaktadır. Leyla ise sadece yüzünde üzüntü ifadesiyle ve yürümekte zorlanır şekilde resmedilmiştir. Leyla'nın bu şekilde bir beden dili ile tasvir edilmesi metin ile paralel bir çıkarım yapmamıza olanak sağlamaktadır. Nakkaş Bihzâd'ın portrecilikteki ustalığı, kişilerin mimiklerini ve duygularını yansıtmada gösterdiği üstün yeteneği buradaki farklı duygulara sahip figürlerle net olarak izleyiciye yansıtılmaktadır. Sahnedeki figürlerin hiçbiri tekdüze resmedilmemiştir. Öte yandan sahnenin doğallığı, gerçek hayattan bir kesit olduğu da sokakta cenaze evinin önünde dilenen bir dilenciye yer verilmesi ile vurgulanmaktadır. Nakkaş Bihzâd'ın olayları bir film sahnesi gibi oldukça gerçekçi olarak resmetmesi, kirşlerin kim olduğu anlaşllacak şekilde bireysel fiziksel ve duygusal durumunu izleyiciye yansıtarak, içinde bulunduğu gerçek mekân ve zamanda, geleneksel kıyafetleri içerisinde tasvir ettiği görülmektedir. 


\subsection{4. (137v) Leyla ve Mecnûn'un Bayılması}
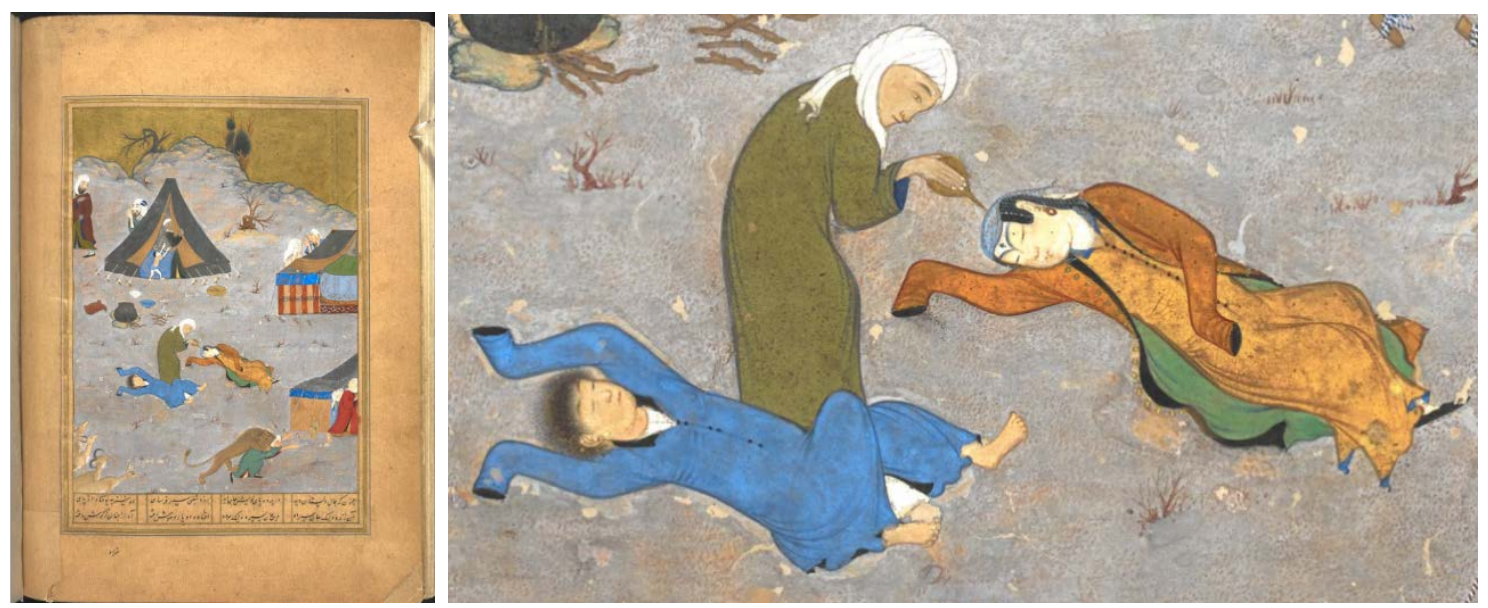

Görsel 7: (137v) Leyla ve Mecnûn'un Bayılması (URL-7, 1490-1499)

Mesnevinin 137 v varağında bulunan Leyla $v$ e Mecnûn'un Bayılması konusundaki sahne, kahramanların kırda karşılaşmasını konu almaktadır. Hikâyeye göre yanına yaklaşan Leyla'yı gören Mecnûn aşırı şekilde heyecanlanır aynı şekilde Leyla da Mecnûn u görünce çok heyecan duyar ikisi de oracıkta bayılır. Etraftaki bir kadın ayılması için Leyla ya gülsuyu döker, Leyla'yı ayıltıp eve götürürler, Mecnûn ayıldığında Leyla'yı göremeyince feryat eder, arkadaşlarına aşk hastası olduğunu söyler, babasına mektup yazar ve "aşığa bunlar ağır gelir" diyerek ayakkabı ve kıyafetlerini çıkarıp ortamdan uzaklaşır. Sahne dikdörtgen formunda, yatay eksende iki kısımda işlenmiş bir kompozisyondan oluşmaktadır. Sahnede zemin açık mavi geniş bir alanı kapsarken gökyüzü ise altın ile renklendirilmiştir. Sahnede günlük yaşantılarını devam ettiren halktan bir kesite yer verilmiştir. Sahnenin zemininde görülen üç ayrı çadırdan birisi tam olarak karşıdan diğer ikisi sağ kenarda yarısı görünecek şekilde tasarlanmıştır. İlk bakışta sıradan bir gün olarak tasarlanan sahnede Mecnûn'un yönettiği aslan, ceylan, oğlak gibi doğada serbest dolaşan hayvanlar görülmekte, bir aslan bir adamın ensesinden yakalamış ısırmaya çalışmakta olduğu görülmektedir. Sahnede sol üstteki profilden görülen çadırın önünde günlük kullanım eşyalarından yemek pişirmeye yaran gereçler, tencere, kâse, kepçe, ocak vb. görülmektedir. Karşıdaki çadırda korkmuş annesine doğru yönelmiş olan bir erkek çocuk ve annesi; aynı çadırın arkasında ise iki bedevi erkek figürü yer almaktadır. Sahnenin solunda alt kısımdaki çadırın içinde iki genç kadın figürü görülürken, üstteki çadırın arka kısmına saklanmış sadece başları görülen iki kadın figürü dikkati çekmektedir. Sahnede toplam on iki insan figürü yer almaktadır. Hikâyenin ana kahramanları Leyla ve Mecnûn sahnenin merkezinde yerde bayılmış şekilde yatmakta bir kadın figürü ise Leyla'nın başına gül suyu dökmektedir. Leyla ve Mecnûn figürleri elleri elbisesinin kolları içerisinde saklanmış şekilde kutsallığı ön plana çıkarılarak resmedilmiştir. Leyla siyah saçlı, beyaz tenli, yuvarlak yüzlü, çekik birleşik kaşlı, önceki iki görseldekine benzeyen tipte resmedilmiştir. Leyla kahverengi iç astarı yeşil olan uzun cüppesinin içine koyu sarı renkte uzun boyda elbise giymiş, başında ise açık mavi başlık ve tülbent bulunmaktadır. Mecnûn figürü ise 128 v deki minyatürdeki gibi siyah kabarık kıvırcık saçlı beyaz tenli genç bir erkeği temsil etmektedir. Önceki minyatürlerdeki tipin aynısı bu görselde de de çizilmiştir. Mecnûn hikâyede anlatılan metinle paralel olarak başında bedevi sarığı ve ayağında ayakkabı olmaksızın mavi renkte giysi ile resmedilmiştir. Her biri figürün kendine has mimik ve duruş ile resmedilmesi diğer minyatürlerde olduğu gibi bu kompozisyonda Bihzâd'ın üslup özelliği olarak dikkati çekmektedir. 


\subsection{5. (144v) Mecnûn'un Leyla'nın Mezarında Ölümü}

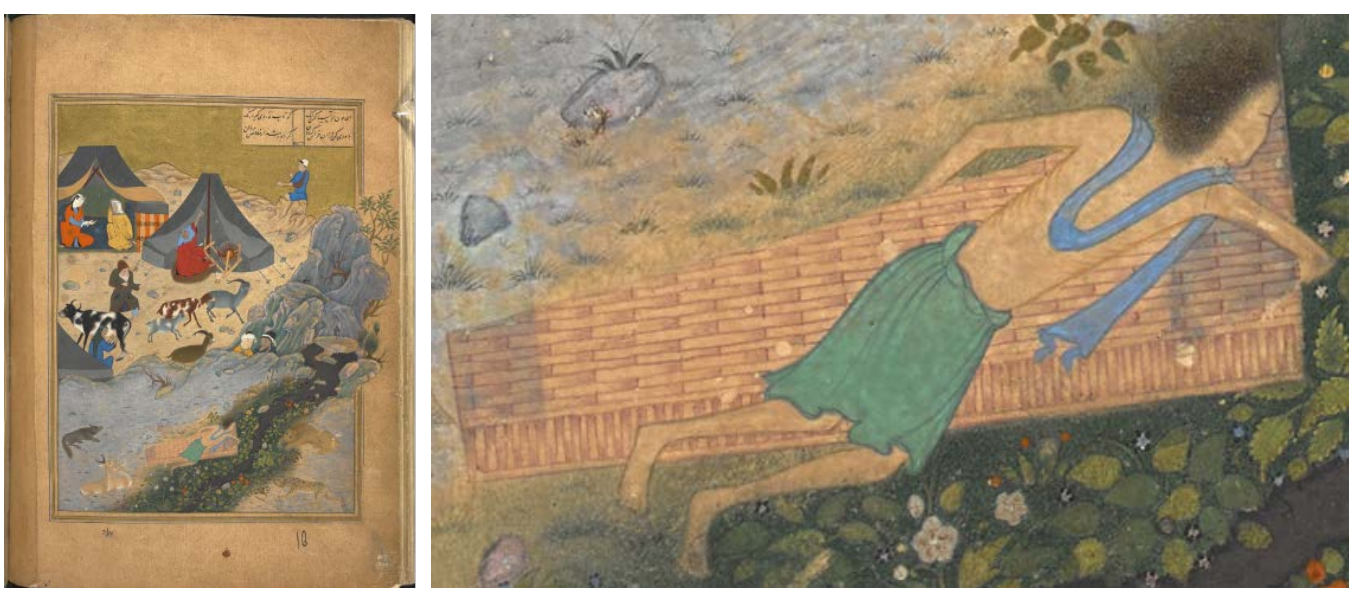

Görsel 8: (144v) Mecnûn'un Leyla'nın Mezarında Ölümü (URL-8, 1490-1499)

Mesnevinin 144 v varağındaki minyatür Leyla'nın öldüğünü öğrenen Mecnûn'un sevgilisinin mezarının başında ölümünü göstermektedir. Bir gün Leylâ çölde onu bulur ama Mecnûn onu tanımaz ve "Leylâ benim içimdedir, sen kimsin?" der. Leylâ, Mecnûn'un ulaştığı mertebeyi anlar ve evine geri döner, üzerinden fazla zaman geçmeden hayata gözlerini yumar. Mecnûn, bunu haber alınca gelip onun mezarına uzanır ve canından can gitmiş gibi hıçkıra hıçkıra ağlar. Feryat figan dualar ederek Allah'tan kendisinin canını almasını, kendisini Leylâ'sına kavuşturmasını ister. Duası kabul olur ve orada hayata veda eder.

Kompozisyon yatay eksende üç kısımdan oluşmaktadır. En alt eksende Mecnûn ve kendisine itaat eden vahşi hayvanlar görülmektedir. İkinci ve aynı zamanda orta eksende günlük yaşantısını sürdüren halktan bir kesite yer verilir iken en üst eksende ise altın ile renklendirilmiş gökyüzü görülmektedir. Sahnenin sağ tarafında cetvellerden dışarı taşan gri renkli dağ kütlesi ile kompozisyona hareket kazandırılmıştır. Kompozisyonun geri kalan kısmı dikdörtgen planlı altın cetveller ile çevrilidir. Sahnede Mecnûn'un etrafında diğer minyatürlerde görülen aynı cins hayvanlar olan pars, aslan, kurt ve ceylanlar görülmektedir. Mecnûn'un ölümü için üzülen bu hayvanlar onun etrafına toplanmış adeta yas tutmaktadır. Mecnûn ise tabuta benzeyen mezar yapısına sarılmış üzüntüsünden kahrolmuş, ölmek için Allah'a yalvarmış ve duası kabul edilerek mezarın üzerinde ölmüş halde tasvir edilmektedir. Leyla yaşadığı şehirden uzakta, çölde olsa bile bir akarsu kenarında çiçekli yeşil bir yerde gömülmüştür. Onun böyle bir fiziki çevrede gömülmüş olması çöldeki vahşi hayvanların yakınında olsa bile adeta cennet bahçesini andıran bir çevrede gömülmesi taşıdığı ilahi kişiliğe işaret olduğunu düşündürmektedir.

Sahnenin ikinci eksenindeki şehirde ise normal devam etmekte olan günlük yaşam tasvir edilmiştir. Minyatürün bu ekseninde iki çadır yer almaktadır. Ön plandaki çadırda kırmızı elbiseli kadın iplik eğirmekte, arka plandaki çadırda ise turuncu ve sarı giysili iki kadın yerde oturmuş karşılıklı sohbet ederken gösterilmektedir. Çadırların önündeki düzlük alanda keçi ve koyunlardan oluşan sürüsünü otlatan yaşlı bir çoban tasvir edilmiştir. Aynı sahnede mavi elbisesi ile siyah beyaz alacalı desenli ineğini sağmakta olan bir kadın görülmektedir. Sahnenin üst eksenindeki uzakta ufuk çizgisindeki diğer çoban ise kavalını çalıyor şeklinde tasarlanmıştır. Sahnede Mecnûn'a yakın alanda dağların arasındaki vadide iki adam ise olup bitenin farkında Mecnûn'un ölümünü bir elini ağzını kapatarak hayret içerisinde izlemektedir. Mecnûn figürü son derece zayıflamış, maddi değil manevi aşkı arama çabaları sonucunda dünyevi olan her şeyden uzaklaşmış, sarık, cübbe, pantolon, ayakkabı gibi dünyevi giysileri "bunlar aşık için fazladır" diyerek reddetmiş altında sadece bir peştamal boynunda ise ince mavi renkte bir örtü ile görülmektedir. Mecnûn Leyla'nın tabuta benzer mezarına adeta sarılmış şekilde yatmaktadır. Mecnûn figürü önceki minyatürlerdeki kişinin saç ve ten rengi özelliklerini taşımış olsa da gerek ölmüş olması gerekse yaş ve fiziksel özellik olarak zayıf düşmesi figürün tasarımına yansıtılmıştır. Nakkaş Bihzâd'ın figürleri resmetmede gösterdiği ustalık sahnede yer alan on dokuz figürün kendine has yaş, fiziksel ve ruhsal durumuna ait karakteristik çizgilerle izleyiciye yansıtılmaktadır. 


\section{Sonuç ve Tartışma}

Bu makalede İran edebiyatının en ünlü mesnevi şairlerinden biri olan Nizâmi Gencevi'nin "Hamse" adlı eserinin 1495-96 yılında telif edilmiş olan minyatürlü nüshası ele alınmıştır. Hamse beş adet mesneviden oluşmaktadır. Bu mesneviler: "Mahzen-ül Esrâr", "Hüsrev ve Şirin", "Leyla ve Mecnûn", "Heft Peyker" ve "İskendername" olarak adlandırılmıştır. Hamse 12. yüzyıldan itibaren, İran başta olmak üzere İslâm dünyasında en çok ilgi gören eserler arasında yer almış gerek saray gerekse diğer ileri gelenler için çok sayıda Farsça, Arapça, Türkçe, Urduca (Durmuş, 2003:159) ve diğer bazı dillerde manzum ve minyatürlü nüshaları hazırlanmıştır. Nüshalar günümüzde başta İran olmak üzere Ülkemizde, Orta Doğu, Avrupa ve diğer çeşitli yazma eser koleksiyonlarında yer almaktadır. Bu çalışmanın konusunu teşkil eden Hamse, Londra'daki İngiliz Kütüphanesi yazma eser koleksiyonunda or.6810 envanter numarası ile kayıtlı olarak muhafaza edilmektedir. El yazma minyatürlü esere kütüphanenin açık erişim sayfasından (http://www.bl.uk/manuscripts/Viewer.aspx?ref=or_6810_f106v) ulaşılmıştır. Çalışmanın örneklemini yazmanın içinde yer alan "Leyla ve Mecnûn" mesnevisi metnini açıklamaya yönelik olarak yapılmış beş minyatür sahnesi oluşturmaktadır. Dönemin Başnakkaşı Kemaleddin Bihzâd'a atfedilen bu minyatürler "(106v) Leyla ve Mecnûn Okulda", "(128v) Mecnûn Çölde Salim Tarafından Ziyaret Edildi", "(135v) Leyla Kocası İbn Salim'in Yasını Tutuyor”, “(137v) Leyla ve Mecnûn'un Bayılması” ve "(144v) Leyla'nın Mezarında Mecnûn'un Ölümü" konularını anlatmaktadır.

Çalışmada, minyatürlerin desen ve tasarım özellikleri, metin ile resim ilişkisi, tasvirlerin metnin kronolojisine uyup umadığı, figürlerin gerçekçi olup olmadığı, resimlerinde realism ve detaylarla ifade gücü kazandırılıp kazandırılmadığı üzerinde durulmuştur. Sanatçının günlük yaşamı nasıl tasvir ettiği gerçek yaşamdam kesitleri tasvirlerine nasıl yansıttığı analiz edilmiştir. Minyatürlerdeki her bir figürün duruş biçimleri, konuşma ve tartışmayı ifade eden hareketlerinin nasıl resmedildiği üzerinde durulmuştur. Çalışma kapsamında, Leyla ve Mecnûn hikayesini açıklamak üzere yapılmış beş adet minyatür değerlendirilmiştir. Araştırma konusu hakkında incelenen ulusal ve uluslararası yayınlar, kitap, dergi, makalelerden elde edilen verilerden, original yazma eserin yüksek çözünürlükteki görsellerinden yararlanılmıştır. Ele alınan beş minyatür ayrı başlıklar halinde önce konusu daha sonra resim anlatılarak analiz edilmiştir. İncelenen minyatürlerde görüldüğü üzere Bihzâd'ın geleneksel İslâm tasvir sanatına yeni bir anlayış getirmiş olduğu söylenebilir. Nakkaş tasvirlerinde minyatür sanatının ana prensibine uyarak metni açıklayıcı olmayı ön planda tutmuş, daha önce belirlenmiş kompozisyon ve kalıpları bire bir olarak kullanmak yerine kendine özgü tarzda geliştirerek kullanmıştır. Sanatçı sıklıkla işlenen saray, saltanat, resmî törenler gibi konulardan ziyade daha seyrek olarak işlenen gündelik yaşam konularını resmetmiş ve bunlarda da olabildiği ölçüde gerçekçi olmaya çalışmıştır. Özellikle detaylarda diğer sanatçılarda görülmeyen ölçüde bir realizmle figürlerine ifade gücü kazandırmıştır. Nakkaşın resimlerinin bir diğer önemli tarafı figürlerin duruş biçimleri, konuşma ve tartışmayı ifade eden hareketleridir. Bihzâd'ın resimlerine oldukça gerçekçi ve yorumcu bir anlam kazandırmak için anlatılan konuya açıklık getiren yüz ifadeleri önemli bir detaydır. Resimlerinin bir diğer özelliği de kullandığı renkler, fırça inceliği ve üstünlüğüdür. Sanatçının en çok sevdiği renkler mavinin tonlarıdır. Gri-mavi renk arasında çeşitli tonlarla belirlenen kayalıklar, araziler, çiçek açmış ağaçlar, kimi zaman sonbahar renklerine bürünen çınarlar büyük bir ustalık ve duyarlılıkla resmedilmiştir. Bihzâd'ın olağanüstü sanat yeteneği konusunda bütün kaynaklar birleşmektedir. Döneminin sanat hamileri ve şairlerinin eserlerinde onun sanat yeteneğinin her zaman rastlanan cinsten olmadığı, mucizevi sanatının bütün tasvir sanatını etkilediği, fırçasının cansız şekillere can verdiği sıklıkla belirtilmektedir. (Çağman, 1992, s. 148). Bu çalışmada analiz edilen beş minyatür sahnesindeki Leyla ve Mecnûn figürleri metnin kronolojisinde olduğu gibi gençlikten yaşlılığa doğru seyir göstermektedir. Leyla ve Mecnûn figürü olayların kurgusu gereği mutlu sahnelerde mutlu mimik yapısında, üzüntülü olaylarda ise mutsuz mimik yapısında; bayıldıklarında yere spontane düşmüş el ve kol postürü ile tasvir edilmiştir. Mecnûn ilerleyen yıllarda ıstırabın artmasıyla zayıflamış, fiziksel olarak güçsüz durumda olduğu tasarımlarda yansıtılmıştır. Mesnevinin Bihzâd'ın adeta imzası gibi olan iri yapraklı çınar ağaçları, mekanlardaki ayrıntılı süslemeci anlayış, ince işlenmiş dağ ve doğa tasvirleri, ırmak kenarlarında detaylı yeşil yapraklı çiçekler her minyatürde öne çıkan desen tasarım özellikleridir. Sanatçının figürlerindeki detaycılık ile dikkati çeken kendine has tarzı açıkça görülmektedir. Nakkaşın tasarımlarda geleneksel kompozisyon kalıplarını kendine özgü 
yorumlayarak kullandığı, dikey ve yatay eksenlerin dengeli kesişimi ile kompozisyonda birbiriyle orantılı alanlar oluşturduğu, her minyatürdeki Leyla ve Mecnûn figürünün birbiriyle örtüştüğü, tasarımlarda kronolojik olarak gençlikten yaşlılığa doğru değişimin göz önüne serildiği, figürlerin yaşadıkları coğrafyanın geleneksel kıyafetleri ve takıları ile resmedildiği sonucuna varılmıştır.

\section{Kaynaklar}

Akalın N. (1998). "Nizâmî-yi Gencevî́nin Hayatı, Edebi Şahsiyeti ve Eserleri”, Bilig Dergisi, Güz, Sayı 7, s. 79-87.

Arslan M. (2007). Türk Edebiyatı'nda Hamse, Türkiye Araştırmaları Literatür Dergisi, Cilt 5, Sayı 9, s.305-322.

Aslanapa, O. 1986. Türk Minyatür Sanatının Gelişmesi. Erdem, 2 (6), 851-866. https://dergipark.org.tr/tr/pub/erdem/issue/44564/552978 (Erişim, 18.10.2021).

Ayan, H. (1979). "Divan Edebiyatında Hamseler", A.Ü. Edebiyat Fakültesi Araştırma Dergisi, Ahmed Caferoğlu Özel Sayısı, Ankara, Sayı 10, s. 87-100.

Blochet E. 1928. Catalogue des manuscrits persans de la Bibliothèque nationale. T. III. Nos 1161-2017. Paris, Réunion des Bibliothèques nationales, Paris, ss. 52-53. https://gallica. bnf.fr/ark:/12148/bpt6k76219t/f59. item (Erişim, 18.10.2021).

Britannica, The Editors of Encyclopaedia, 2021. "Neẓāmī". Encyclopedia Britannica, https://www.britannica.com/biography/Nezami (Erişim, 1.1. 2021).

Çağman, F. 1992. "Bihzâd Kemâleddin, Üstâd", TDV İslam Ansk, C.6, ss.147. https://cdn2.islamansiklopedisi.org.tr/dosya/6/C06002286.pdf (Erişim, 21.10.2021).

Çavuşoğlu H. (2013). İki Farklı Kültürün Âşık Kadın Kahramanları: Leyla Ve Züleyha, Turkish Studies - International Periodical For The Languages, Literature and History of Turkish or Turkic Volume 8/13 Fall, p. 645-670, Ankara.

Çelik, H., Baykal N., Kılıç Memur H. (2020), "Nitel Veri Analizi ve Temel İlkeleri", Eğitimde Nitel Araştırmalar Dergisi - ENAD, Journal of Qualitative Research in Education - JOQRE, Cilt 8 / Sayı 1, 2020, SS. 379.

Dilperîpûr, A. (1999) "Türk Edebiyatında Nizâmî'nin Takipçileri ve Hamse'sine Nazire Yazanlar", çev. M. Fatih Köksal, Türklük Bilimi Araştırmaları, Sayı 8, s. 199-238.

Durmuş İ. 2003. "Leyla ve Mecnûn Maddesi", TDV İslam Ansk, C.27, ss.160. https://cdn2.islamansiklopedisi.org.tr/dosya/27/C27023979.pdf (Erişim, 17.10.2021)

Kanar, M. 2007. "Nizâmî-i Gencevî". TDV İslam Ansk. C. 33, İstanbul: Türkiye Diyanet Vakfı Yayınları, s. 183-185.

Karahan, A. 1996. "Fuzuli Maddesi", TDV İslâm Ansk., İstanbul, C. 13. ss. 240-246 https://islamansiklopedisi.org.tr/fuzuli (Erişim, 17.10.2021)

Kaska, Ç. (2020). "Fars Edebiyatındaki Hamseler". Uludağ Üniversitesi FenEdebiyat Fakültesi Sosyal Bilimler Dergisi, C. 21, S. 39, s. 877-914. DOI: 10.21550/sosbilder.608354 (Erişim, 17.10.2021).

Kılıç H. 1994. “Ebü'l-Ferec El-İsfahânî Maddesi”, TDV İslâm Ansk., İstanbul, C.10. ss. 316-318 https://islamansiklopedisi.org.tr/ebul-ferec-el-isfahani (Erişim, 17.10.2021).

Martin, F. R., T. W. Arnold, 1926 The Nizâmî Ms., Illuminated by Bihzâd, Mirak and Qasim Ali, Written 1495 for Sultan Ali Mirza Barlās, Ruler of Samarquand, in the British Museum (Or. 6810) Vienna.

Pala İ. (2003) "Leyla ve Mecnûn Türk Edebiyatı Maddesi", TDV İslam Ansk, C.27, ss.160. https://islamansiklopedisi.org.tr/leyla-ve-Mecnûn\#1 (Erişim, 17.10.2021).

Ritter, H. 1955. Die frühgeschichte der erzählung von Macnūn und Lailā in der arabischen Literatur ((Ранняя история повести о Меджнуне и Лейле в арабской литературе), Oriens Vol. 8, No. 1 (Oct. 30, 1955), pp. 1-50 (50 pages) Published by: Brill https://doi.org/10.2307/1579465 (Erişim, 04.10.2021). 
Sağlam, H. (2021). Leylâ vü Mecnûn Mesnevîlerinde Bulunan Bazı Motiflerin Dinî ve Tarihî Kökenleri. Akademik Dil ve Edebiyat Dergisi, 5 (2), 1415-1433. https://doi.org/10.34083/akaded.952161 (Erişim, 1.10.2021).

Sever, S. 2020. "Nîsâbûrî'nin (Sa'lebî) 'Kısas-ı Enbiyâ' Adlı Eserindeki Minyatürlerde Melek Figürü ve Özgün Tasarımlar" Danışman: Doç. Filiz Adıgüzel Toprak, Dokuz Eylül Üniversitesi, Güzel sanatlar Enstitüsü, Sanatta Yeterlik Tezi. https://tez.yok.gov.tr/UlusalTezMerkezi/tezSorguSonucYeni.jsp (Erişim, 1.10.2021).

Seyller, J (1997). "The Inspection and Valuation of Manuscripts in the Imperial Mughal library", Artibus Asiae 57 no 3/4, pp. 243-349.

Şenocak, E. 2000. Leyla ile Mecnûn Hikayesi Üzerine Mukayeseli Bir Araştırma, Yüksek Lisans Tezi, Fırat Üniversitesi, Sosyal Bilimler Enstitüsü, Türk Dili ve Edebiyatı Anabilim Dalı, Danışman, Yrd. Doç. Esma ŞİMŞEK, Elâzığ. file:///C:/Users/IDU/Downloads/74617.pdf (Erişim, 17.10.2021).

Titley, Norah M. 1977 Miniatures from Persian Manuscripts: a Catalogue and Subject Index of Paintings from Persia, India and Turkey in the British Library and the British Museum, London, p. 141.

Yavuz, Seyit (2018). "Kitabiyat, Ali Nihad Tarlan Tarafından Tercüme Edilen Leyla ile Mecnûn'un Yeni Baskısı Üzerine", HİKMET-Akademik Edebiyat Dergisi [J ournal of Academic Literature], Prof. Dr. Ali Nihad Tarlan Özel Sayısı Yıl 4, Aralık, ss.705-712. https://dergipark.org.tr/en/pub/hikmet/issue/41411/492719 (Erişim, 01.10.2021).

Yazıcı T. 2003. "Leyla ve Mecnûn Fars Edebiyatı Maddesi", TDV İslam Ansk, C.27, ss.160. https://islamansiklopedisi.org.tr/leyla-ve-Mecnûn\#1 (Erişim, 17.10.2021).

Yazıcı T. ve Kurnaz. 1999. "Hamse", TDV İslam Ansk., İstanbul, C. 15, s. 499-500. https://cdn2.islamansiklopedisi.org.tr/dosya/15/C15005440.pdf (Erişim, 17.10.2021).

URL-1, (2021).

https://www. britannica.com/biography/Nezami/imagesvideos\#/media/1/413374/111512 (Accessed in: 17.10.2021), (In England).

URL-2, (2015).

http: //www.allaturkaa.de/forum/index.php?page=Thread\&threadI D=93709\&pageNo=1

(Erişim: 17.10.2021), (In Turkish).

URL-3, (1490-1499). http://www.bl.uk/manuscripts/Viewer.aspx?ref=or_6810_f001r (accessed in: 20.10.2021), (In United Kingdom).

URL-4, (1490-1499). http://www.bl.uk/manuscripts/Viewer.aspx?ref=or_6810_f106v (accessed in: 20.10.2021), (In United Kingdom).

URL-5, (1490-1499). http://www.bl.uk/manuscripts/Viewer.aspx?ref=or_6810_f128v (accessed in: 20.10.2021), (In United Kingdom).

URL-6, (1490-1499). http://www.bl.uk/manuscripts/Viewer.aspx?ref=or_6810_f135v (accessed in: 20.10.2021), (In United Kingdom).

URL-7, (1490-1499). http://www.bl.uk/manuscripts/Viewer.aspx?ref=or_6810_f137v (accessed in: 20.10.2021), (In United Kingdom).

URL-8, (1490-1499). http://www.bl.uk/manuscripts/Viewer.aspx?ref=or_6810_f144v (accessed in: 20.10.2021), (In United Kingdom). 


\section{Extended Abstract}

The study material consists of the miniature copy of the 'Khamsah' of Nizāami Ganjavī (D.114041 ), one of the most famous masnavi poets of I ranian literature, which was compiled in 149596. Hamse consists of five masnavi. These masnavis are called Makhzan al-asrār', 'Khusraw u Shīrīn', 'Laylā u Majnūn' and 'Haft paykar' and 'Iskandarnāmah'. Khamsah has been among the most remarkable works in the Islamic world, especially in Iran, since the 12th century. copies have been prepared. Today, its copies are in Iran, in our country, in the Middle East, in Europe and in various manuscript collections. The subject of this study, Hamse, is preserved in the manuscript collection of the British Library in London as inventory number or .6810. The manuscript miniature was accessed from the library's open access page (http://www.bl.uk/manuscripts/Viewer.aspx?ref=or_6810_f106v). The sample of the study consists of five miniature scenes made to explain the text of the "Laylā U Majnūn " masnavi. These miniatures attributed to the Naqqash Kemaleddin Bihzâd, are as follows: "(106v) Leyla and Majnun at School", "(128v) Majnun Visited by Salim in the Desert", "(135v) Leyla Mourns Her Husband Ibn Salim", "(137v) Leyla and Majnun Fainting" and "(144v) Majnun's Death in Layla's Grave".

In the study, the pattern and design features of the miniatures, the relationship between the text and the picture, whether the depictions are suitable for the chronology of the text, whether the figures are realistic, whether they gain realism and expressive power with details were examined. Is emphasized. How the artist depicts daily life and how he reflects sections from real life to his depictions has been examined. In the miniatures, the postures of each figure and how their movements expressing speech and discussion are depicted are emphasized. Within the scope of the study, five miniatures made to tell the story of Leyla and Majnun were evaluated. Data from national and international publications, books, journals, articles and high-resolution images of the original article were used. Five miniatures were examined under separate headings by first explaining the subject and then the painting. Nakkaş Bihzâd, who is the artist of the mentioned miniatures, kept the text in the foreground by following the main principle of miniature art in all his depictions, and generally preferred not to use predetermined compositions and patterns. In this work, Nakkaş preferred daily life depictions such as miniatures and succeeded in being realistic in these depictions. He gave expressive power to his paintings with a realism that has never been seen before, especially in the details. Another important aspect of his paintings is the poses of the figures, their movements expressing speech and discussion. On the other hand, the facial expressions that clarified the subject gave a very realistic and interpretive meaning to his paintings. The colors he uses, the fineness and superiority of the brush are another feature of his paintings. It is seen that the artist paints rocks, fields, blooming trees, plane trees, which sometimes take on autumn colors, with great mastery and precision. It is seen that the painter uses various tones between blue and grayblue in his mountain depictions. Leyla and the majestic figures in these miniature scenes show a course from youth to old age, as in the chronology of the text. Leyla and the majestic figure have a happy mimic structure in happy scenes and unhappy in sad events due to the setting of events; It is depicted with a hand and arm posture that spontaneously falls to the ground when they faint. In the following years, Majnun weakened with increasing suffering, and his physical weakness was reflected in the designs. Large-leafed plane trees, which are like Bihzâd's signature in the masnavi, detailed ornamentation in the spaces, finely worked mountain and nature depictions, detailed green-leafed flowers on the riverbanks are the prominent pattern design features in masnavis. The unique style of the artist, who draws attention with the detailing in each miniature figure, is clearly seen. The painter uses traditional composition patterns in his designs by interpreting them in his own style, creating proportional areas in the composition with the balanced intersection of the vertical and horizontal axes, and the figures of Leyla and Majnun overlap each other in each miniature. It has been concluded that the chronological change from youth to old age is revealed in the figure design of the muralist, and the figures are depicted with the traditional clothes and jewelry of the geography they live in. 